\title{
Hausa-English Code-switching in Kanywood Films
}

\author{
Chamo Isa Yusuf \\ Department of African Languages and Cultures, University of Warsaw \\ Krakowskie Przedmiescie 26/28 00-927 Warszawa, Poland \\ Tel: 48729220851 E-mail: iychamo@yahoo.com
}

$\begin{array}{ll}\text { Received: February 25, } 2012 & \text { Accepted: March 11, } 2012 \quad \text { Published: June 1, } 2012 \\ \text { doi:10.5296/ijl.v4i2.1766 } & \text { URL: http:/dx.doi.org/10.5296/ijl.v4i2.1766 }\end{array}$

\begin{abstract}
This work focuses on Hausa-English code-switching in contemporary Kanywood films. The nature of code-switching in the films, as well as reasons for code-switching are all examined. It is noted that code-switching in Kanywood films is mostly influenced by characters' emotional situation (love or sadness). Only in few cases the characters use the phenomenon to share an identity with a member of their group. The paper also argues that code-switching in Kanywood films is a conscious behavior as opposed to unconscious one in spontaneous conversation.
\end{abstract}

Keywords: Hausa, English, Kanywood films, Code-switching 


\section{Introduction}

Kanywood is the name of the Hausa film industry based in Kano in northern Nigeria. Due to the cosmopolitan nature of Kano and the fact that most of the production is placed there, in 1999 a journalist working with a Hausa newspaper called Tauraruwa coined a name KANYWOOD for the industry. The first commercial Hausa film Turmin Danya (1990, directed by Daudu Galadanci) was produced by Tumbin Giwa Production, Kano. After the successful marketing of the film many people became engaged in film production. Currently it is estimated that over 2000 companies are registered with Kano state film makers association apart from others across northern Nigeria and Nigeria at large. The language of communication in the film is Hausa. However as a result of contact between the Hausa with the British in 1903 and the use of English as Nigeria's official language and language of instruction at schools, some of the film actors are bilingual which is reflected in their conversations in the films.

Code-switching is broadly studied in linguistics and related fields. Linguistic researches on code-switching usually focus on grammatical perspective and sociological point of view. A grammatical approach focuses on the structural aspects of code switching which determine the syntactic or morphosyntactic constraints on language alternation (e.g. Poplack 2000; Sankoff and Poplack 1981; Joshi1985; Belazi et al. 1994; and Halmari 1997). A sociolinguistic approach is concerned with the role of social factors in the occurrence of code switching, such as context and speakers' role relationships see (Blom and Gumperz's 1972; Gumperz 1974; 1982; Myers-Scotton 1993; Rampton 1995; Benson 2000; Milroy \& Muyasken 2005 and Danyaro 2011).

Sociolinguists define code-switching as "the use of more than one language in the course of a single communicative episode" Heller's (1988:1). Grosjean (1982:147) mentions that "Code-switching is the alternation in the use of two languages (or even more) in the same discourse. The switch can happen within words, clauses, or sentences. However, there is only a switch in the language, not an integration of the word, clause or sentence into the other language.” Also Auer \& Myers-Scotton, who largely disagree on how or why code switching occurs, nonetheless sound quite similar in their definitions of the phenomenon. Auer (1984:1) refers to code-switching as "the alternating use of more than one language," while Myers-Scotton (1993: vii) mentions that it is "the use of two or more languages in the same conversation.” Then Gumperz (1982:59) defines it “as the juxtaposition within the same speech exchange of passages of speech belonging to two different grammatical systems or subsystems".

\section{Reasons for Code-Switching}

Bilingual speakers switch from one language variety to another for many communicative purposes. But what it is important is close observation of behavior in particular settings than to generally applicable explanations of linguistic capability. As Gumperz (1982) emphasizes that close analysis of brief spoken exchanges is necessary to identify and describe the function of code-switching. Also Bollinger 1975:257) points out that code-switching may be carried out so as to clear any obstacle that may arise in the course of communication. He 


\section{Macrothink}

International Journal of Linguistics

ISSN 1948-5425

2012, Vol. 4, No. 2

further claims that switching is carried out sometimes by a speaker whose deliberate intention is to deceive, disguise or brag to the hearer.

In addition Karen (2003) listed a few possible conditions for code switching as follows:

-Lack of one word in either language

-Some activities have only been experienced in one of the languages

-Some concepts are easier to express in one of the languages

-A misunderstanding has to be clarified

-One wishes to create a certain communication effect

-One continues to speak the language latest used because of the trigger effect

-One wants to make a point

-One wishes to express group solidarity

-One wishes to exclude another person from the dialogue.

Similarly, Malik (1994) accounts ten reasons for code-switching

Lack of Facility

Lack of Register

Mood of the Speaker

To emphasize a point

Habitual Experience

Semantic significance

To show identity with a group

To address a different audience

Pragmatic reasons

To attract attention

This paper study code-switching in contemporary Hausa films and analyzes characters' dialogues which show how the phenomenon is manifested. The technique of contextual analysis was employed for interpretation of the data with reference to the situation and hero's status. The nature of code-switching in the films, as well as reasons for code-switching, are all examined.

\section{Methodology}

The data used for this research was collected from three Kanywood films namely Khaleesat 1 (2011, directed by Alkali Kamal), Wasila1 (2010, directed by Nuhu Ali) and Mata da Miji 
(directed by Saira Aminu). The films were randomly selected and watched three times by the researcher. They differ in terms of directors, production companies, years of production and places of production.

Khaleesat 1 tells a story of a couple Ibrahim and Khaleesat. The title is the name of the main female character Khaleesat. Khaleesat is a successful banker and Ibrahim is a school teacher. They live a happy life of mutual understanding, trust and respect. The situation changes when Ibrahim receives some text messages from a stranger that he should be careful about his wife activities in the bank and watch her coming home late due to the nature of her works. That leads Ibrahim to suspicious behavior towards his wife. The audience knows however that the man who sends the text messages to Ibrahim wanted to have affairs with Khaleesat and promises her to open a bank account and deposit a huge mount of money in the bank if she agrees to his proposal, but she rejects it. The suspicion between Ibrahim and Khaleesat leads to their separation.

Wasila 1 is a love story about Jamilu a banker and his educated wife Wasila. The film shows that Jamilu has no enough time to stay at home with his wife due to his works. As a result one day the wife invited her former boyfriend Muda to their house after the husband left to office. When Jamilu gets to the office his manager ask him for a file that he had given him to keep. Jamilu left the file at home. So, he returns to take it. When he reaches the house he sees his wife with her former boyfriend in the bedroom, which causes the end of their relationship.

Mata da Miji describes a story of working class couple, Abdurra'uf a medical doctor and Maijidda a banker. The film shows that the couple is not be able to take care of their son Sudais due to their work. They decide to hire a nanny called Rukayya. Sudais and Rukayya become so intimate like a son and a mother. As a result, the son refuses to get back to his parents, which annoys the father. Abdurra'uf suggests to his wife that one of them should give up the work in order to take care of the son. The wife refuses to stop working, so he is forced to give up his job to take care of the son. His resignation does not solve the problem due to the close relation between the son and his nanny. Then the father decides to marry the nanny but his wife opposes the plans. But Dr. Abdurra'uf was able to marry the nanny with all the oppositions from the wife. After the marriage the father finally gets his son's attention and Maijidda is left with guilt and remorse.

\section{The Data}

I present here sample of Hausa-English utterances from the corpus of collected data. English is written in plain, while Hausa is italicized. The gloss in English is written below each utterance. Each utterance is numbered for easy reference in the discussion.

\section{Thank you sir. Sai an jima. Khaleesat-manager}

Thank you sir. See you next time

(2). Aliyu kar ka manta ni matar aure ce, idan ka manta na tuna maka. Leave my office now. Khaleesat-Aliyu

Aliyu do not forget that I'm married if you forget let me remind you. Leave my office now 
(3). You are very stupid. Kin yaudare ni Ibrahim-Khaleesat 2012, Vol. 4, No. 2

You are very stupid. Y You have deceived me.

(4). Please wait! Duk wadanda suke taimakona babu kamar ki. Manager-Khaleesat Please wait! Among all my assistances there is no one like you

(5). Okay zan tafi ofis. Khaleesat-Ibrahim

Okay I will leave to office

(6). Wasila yi hakuri! I love you. Jamilu-Wasila

Wasila be patient! I love you

(7). To ai ya kamata ka dauki casual leave. Wasila-Jamilu

You suppose to take a casual leave

(8). Na ji maganarku amma ina so naga Jamilu. I just missed him. Wasila-Friends

I heard your views but I need to see Jamilu. I just missed him

(9). Gaskiya ne corruption is a cancer to us. Jamilu-Manager

You are right corruption is a cancer to us.

(10). This is an expensive joke. Gaskiya kar ku sake yi mini wannan. Jamilu-Saliha

This is an expensive joke. Please do not do it again.

(11). Look sweet heart a bar wannan maganar. Jamilu-Wasila

Look sweet heart let leave this issue

(12). Look! Kar ki tsai da ni sai na dawo. Jamilu-Wasila

Look! Do not delay me, see you later

(13). Bari na je ayi mana take away. You spoiled my mood today.

Let me go an have a take away for us. You spoiled my mood today. Jamilu-Wasila

(14). Na kirawo ka ne don na gaya maka I’m now free. Wasila-Moda

I just called to inform you that I'm free now

(15). Haba Abdul! Yaron nan is just a small boy. Maijidda-Abdurra'uf

Oh Abdul! This boy is just a small boy

(16). Za ki iya kashe T.V? I want discuss an important issue with you. Abdurra'uf- Maijidda

Can you switch off the T.V? I want discuss an important issue with you.

(17). I'm sorry. Gaskiya ni ba zan iya aji ye aikina ba. Maijidda-Abdurra'uf 
I’m sorry. To be sincere I can not resign from my job.

(18). Okay. Ni zan aji ye nawa aikin. Abdurra’uf- Maijidda

Okay. I will resign from my job.

(19). Shakuwar yaron nan da matar nan is too much. Maijidda-Abdurra'uf

The intimacy between this boy and his nanny is too much.

(20). Sai dai ki ce ba ta da aiki but she is educated enough. Abdurra'uf- Maijidda

You can only say that she is jobless but she is well educated.

\section{Analysis}

The procedure for the analysis was based on insights from other studies. Following Gumperz (1982), situational code-switching, but different from what happens in situations described by Ferguson (1972) and others as diglossia, where two languages or varieties co-exist and are specialized according to functions. Wardhaugh (2006) describes how situational code-switching occurs:

Situational code-switching occurs when the languages used change according to the situations in which the conversant find themselves: they speak one language in one situation and another in a different one. No topic change is involved. Instances of situational code-switching are usually fairly easy to classify for what they are. What we observe is that one variety is used in a certain set of situations and another in an entirely different set. However, the changeover from one to the other may be instantaneous. Sometimes the situations are so socially prescribed that they can even be taught, e.g., those associated with ceremonial or religious functions (Wardhaugh 2006:104).

However, code-switching in Kanywood films could be described as situational as most of the given examples were made during a certain situation. Therefore two factors account for code-switching in the films emotional situation (love/sadness) or what Malik (2004) describes as mode of a speaker and showing of an identity which corresponds with one of the reason for code-switching describes by Karen (2003) 'one wishes to express group solidarity'. This shows that Kanywood films characters usually switch to English when they are in emotional state or if they want to share identity with a person or group.

In example 1, Khaleesat switch to English to thank her manager after given her some advice on not quit her job, after she tenders a letter of resignation to him for approval. She does so, as a result of excessive pressure from her husband and his mother due to her job conditions. It shows that her switch to English was motivated by her situation of annoyance and disorientate. Also in Example2, Khaleesat switch to English when she was angry to remind her co-worker Aliyu that she is married, when he tells her that she is close to the manager.

Example3 shows that Khaleesat husband's Ibrahim speaks English to her when she comes home late from the office. The husband went to the bank and peeps through the window where he sees her discussing with manager in the manger office which annoys him and 
causes him to suspect her of having affairs with the manager. Code-switching in examples4 was motivated by sadness because the manager informs Khaleesat that she is important to the bank after she submits a letter of resignation from the job.

Example5\&9 could be described as sharing of identity. In example5 Khaleesat shares her identity of an educated person with her husband Ibrahim while example 9 Jamilu switch to English to share identity with his manager of having knowledge of the English language. That is why in all the talks with their parents, parent in-laws, and elderly people, characters do not switch to English, they use Hausa instead. As Wardhaugh (2006:110) explains that 'Code-switching can allow a speaker to do many things: assert power; declare solidarity; maintain certain neutrality when both codes are used; express identity; and so on.

Examples6, 7\&8 were made by Jamilu a banker and his educated wife Wasila when they were still in mutual love. The wife complains to the husband that she does not want him to leave her alone. The husband pleads with her to be patient and says he loves her. Example 14 also indicates intimate situation as Wasila tells to her former boyfriend Moda that they can continue their relationship.

Similarly, examples 10 are a statement made by Jamilu when he sees his wife Wasila in good condition after having been in coma. Examples 11, 12 \& 13 were pronounced when the characters were in dismay. In example11 \&13 Jamilu switch to English after being told by his wife's that the person he sees talking to her while he pays the food bill was her former boyfriend Moda. Example 14 was uttered when Wasila delays Jamilu to office. Example 15, 16, 17, 18, 19 \& 20 were made by Maijidda and her husband's Abdurra'uf to each other when they were in distress. Abdurra'uf wants to marry the second wife in order to get his son attention while Maijidda opposed the plans and feels dismayed.

Code-switching in Kanywood film can be linked to an emotional situation (love/sadness) and sharing of an identity with a person or group. The use of code-switching in the films could be describe as a conscious phenomena as opposed to Wardhaugh (2006) assertions in spontaneous conversation that it is an unconscious behavior. As the phenomenon it is normally appears in younger generation's dialogue in the films. The younger generation's do not switch to English when speaking to their parents or elders in the film only in some situations when they want to portray a character's behavior like someone who was brought up in the Western countries or stayed there for a long period of time.

\section{Nature of code-switching in Kanywood Films}

Romanie (1994:57) divide code-switching into three types, Inter-sentential switching, intra-sentential code-switching and tag-switching.

\subsection{Inter-sentential switching}

Involves a switch at a clause or sentence level, while each clause or sentence is in one language or another (Romanie1994). This kind of switching exists in examples 1, 2, 3, 4, 6, 8, $10,13,16$ and 17 of the given data.

It is noted that inter-sentential code-switching in Kanywood films dialogues involves the use 
of English clauses part at the beginning of a sentence or statement as in examples, 1, 3, 4, 7, 8 and 10.

\subsection{Intra-sentential switching}

Intra-sentential switching is characterized by a switch from one language variety to another within a single utterance, or a switch within the clause or sentence boundary. Inter-sentential code-switching appears in examples 7, 9, 11, 14, 15, 19 and 20 in the films studied.

\subsection{Tag-switching}

Involves the insertion of a tag in one language into an utterance which is otherwise entirely in the other language. (e.g. well, you know, okay, I mean, right, etc). This types of code-switching manifests in examples 5, 12, and 18.

It is clear that the inserted tags function in Kanywood films as it does in English context as seen in the above examples.

\section{Conclusion}

This paper shows that code-switching in Kanywood films was motivated mostly by character situation in a dialogue. The paper also showed two function of code-switching in the film: to display emotional situation and to share identity with a group member. It also shows that code-switching usually appears in dialogues of a younger generation and it hardly appears when a young person talks to his parents or to elders. However, situation and participants determine the use of the code-switching in the film as the phenomena is not shown in a dialogue between younger generations with their parents, elders or between elderly characters. The characters used Hausa in their dialogues as the language of narration, assertion and interpretation while English was used as the language of status. The frequent use of code-switching in the films makes it difficult for monolingual and elder audience to follow the film and to decode the characters' dialogues.

\section{Acknowledgement}

This paper receives significance contributions from many people. I'm grateful to my supervisor Prof. Nina Pawlak for her constructive contributions. In addition I'm deeply indebted to Prof. Abdalla Uba Adamu for his useful comments and Dr. Izabella Will for reading the manuscript and offer some suggestions.

\section{References}

Amin, B. D. (2011). Code-switching in the Kano State House of Assembly. FAIS Journal of Humanities, 5, 1, 1-14.

Auer, P. (1984). Bilingual Conversation. Amsterdam: John Benjamins.

Belazi, H., Edward R., \& Almeida, J., T. (1994). Code-switching and X-Bar Theory: The Functional Head Constraint. Linguistic Inquiry 25, (2), 221-237.

Benson, E. (2001). The Neglected Early History of Code-switching Research in the United 


$\begin{array}{lllll}\text { States. } & \text { Language } & \text { C } & \text { Communication } & 21,\end{array}$

http://dx.doi.org/10.1016/S0271-5309(00)00012-4

Blom, J., \& Gumperz, J. (1972). Social Meaning in Linguistic Structures: Code Switching in Northern Norway. In: Gumperz, J. \& Hymes, D. (eds.). Directions in Sociolinguistics: The Ethnography of Communication, 407-434. New York: Holt, Rinehart, and Winston.

Bolinger, D. (1975). Aspects of language. New York: Harcourt.

Ferguson, C. F. (1972). Diglossia. In Gigliolo, P. (eds.). Language and Social Context, 232-252. Harmondsworth: Penguin.

Grosjean, F. (1982.). Life with two languages. Cambridge, MA: Cambridge University Press.

Gumperz, J. (1982). Discourse Strategies. Cambridge: Cambridge University Press. http://dx.doi.org/10.1017/CBO9780511611834

Halmari, H. (1997). Government and Code-switching: Explaining American Finnish. Amsterdam: John Benjamins.

Heller, M. (1988). Code-switching: Anthropological and Sociolinguistic Perspectives. Berlin: Mouton de Gruyter. http://dx.doi.org/10.1515/9783110849615

Joshi, A. (1985). How much Context-sensitivity is Necessary for Assigning Structural Descriptions: Tree Adjoining Grammars. In Dowty, D., Karttunen, L., \& Zwicky, A. (eds.). Natural Language Parsing. Cambridge: Cambridge University Press.

Karen, K., Y. C. (2003). Code-switching for a Purpose: Focus on Preschool Malaysian Children. Multilingua, 22, 59-77. http://dx.doi.org/10.1515/mult.2003.004

Malik, L. (1994). Sociolinguistics: A Study of Code-switching. New Delhi: Anmol.

Milroy, L., \& Muysken, P. (eds.). (1995): One Speaker, Two Languages: Cross-Disciplinary Perspectives on Code-switching. Cambridge: Cambridge University Press.

Myers-Scotton, C. (1993). Social Motivation for Code-switching: Evidence from Africa. Oxford/New York: Oxford University Press.

Poplack, S. (2000). Sometimes I'll start a sentence in Spanish y termino en Espanol: Toward a typology of code-switching. In Li W. The Bilingualism Reader. UK: Routledge.

Rampton, B. (1995). Crossing: Language and Ethnicity among Adolscents. London: Longman.

Romaine, S. (1989). Bilingualism. Oxford: Basil Blackwell.

Romaine, S. (1994). Language in Society: An introduction to Sociolinguistics. New York: Oxford University Press.

Sankoff, D., \& Shana, P. (1981). A Formal Grammar for Code-Switching. Papers in Linguistics 14, (1-4), 3-45. 


\section{Macrothink}

International Journal of Linguistics ISSN 1948-5425 2012, Vol. 4, No. 2

Wardhaugh, R. (2006). An Introduction to Sociolinguistics, (5nd ed.): U.S.A. Blackwell Publishers.

\section{Filmography}

Asnanic, F. N. (producer), \& Saira, A. (director). (2009). Mata da Miji (husband \& wife). Nigeria: G. Top Multi-media, Abuja.

Lere, Y. (producer), \& Nuhu, A. (director). (2010). Wasila1 (a female name). Nigeria: Lerawa Film, Kaduna.

Miko, Y. A. (producer), \& Alkali, K. (director). (2011). Khaleesat1 (a female name). Nigeria: Faidat Production, Kano. 